\title{
HUBUNGAN SANITASI SUMUR GALI DAN KUALITAS BAKTERIOLOGIS DENGAN PREVALENSI DIARE INFEKSI DI DESA PANGEBATAN KECAMATAN KARANGLEWAS KABUPATEN BANYUMAS TAHUN 2016
}

\author{
Aditya Puspitasari1 $^{1)}$, Choiroel Anwar ${ }^{2)}$ \\ Jurusan Kesehatan Lingkungan, Politeknik Kesehatan Kemenkes Semarang, \\ Jl. Raya Baturaden KM 12 Purwokerto, Indonesia
}

\begin{abstract}
Abstrak
Diare infeksi adalah diare yang disertai demam atau lender atau darah dalam tinja yang disebabkan virus, bakteri, dan parasit. Gejala yang ditimbulkan demam, nyeri kepala, mual, dan muntah. Salah satu faktor yang menjadi penyebab timbulnya penyakit diare infeksi yaitu factor lingkungan (sanitasi dan konstruksi sumur gali, kualitas bakteriologis dan perilaku penggunaan sarana air bersih). Penelitian yang digunakan adalah metode analitik dengan pendekatan Cross Sectional. Jumlah populasi sebesar 168 sumur dengan dengan teknik random sampling dan metode cluster sampling mengambil 20\% didapat sampel sebanyak 34 sumur. Variabel yang diteliti sanitasi sumur gali, kualitas bakteriologis dan perilaku pengguna sumur gali. Analisis data secara univariat dan bivariat dengan menggunakan uji statistik Chi square $\left(X^{2}\right)$. Hasil penelitian menunjukan sanitasi sumur gali dengan prevalensi diare tidak terdapat hubungan sebab $X^{2}$ diperoleh nilai $P=0,513(P>0,05)$; tidak terdapat hubungan kualitas bakteriologis dengan prevalensi diare sebab $X^{2}$ menunjukan nilai $P=0,546$ (nilai $p>0,05$ ); ada hubungan signifikasi perilaku pengguna dengan prevalensi diare menunjukan nilai $P=0,031$ (nilai $P<0,05$ ). Kesimpulan penelitian ini sanitasi sumur gali dan kualitas bakteriologis tidak memiliki hubungan yang bermakna. Faktor yang memiliki hubungan dengan terjadinya diare yaitu perilaku pengguna sumur gali. Peneliti menyarankan agar masyarakat selalu menjaga kebersihan lingkungan dan menerapkan hidup bersih dan sehat.
\end{abstract}

Kata kunci : Sanitasi Sumur Gali

\begin{abstract}
Diarrhea infection is diarrhea which is together with fever or mucus or blood in feces caused by viruses, bacteria, and parasites. The symptoms are fever, headache, nausea, and vomiting. Environmental factor is considered as one factor causing infectious diarrhea, such as sanitary and well construction, the bacteriological quality and behavior in using clean water). The research applied analytic method with cross sectional approach. The populations of this research were 168 wells, selected with random sampling technique and cluster sampling method was resulted 20\% samples as many as 34 wells. The variables in this study were well sanitary, quality of bacteriological and behavior of well users. The data analyzed by univariate and bivariate with statistic test Chi-square $\left(X^{2}\right)$. The results showed no relation between well sanitation and prevalence of diarrhea because $X^{2}$ obtained value of $P=0.513(P>0.05)$; there is no relationship between bacteriological quality with the prevalence of diarrhea because X2 shows the value $P=0.546$ ( $p$-value $>0.05$ ); there is a significance relationship between the user' behavior and the prevalence of diarrhea with $P$ value $=0.031(P<0.05)$. The conclusion shows, there is no significant correlation between well' sanitary and bacteriological quality. A factor that is having relationship with the occurrence of diarrhea was the behavior of well's user. The researcher suggests people to maintain a clean environment and apply clean and healthy life.
\end{abstract}

Kata kunci : Dug Well Sanitations

\section{PENDAhUluan}

Pembangunan kesehatan bertujuan untuk meningkatkan kesadaran, kemauan, dan kemampuan hidup sehat bagi setiap orang agar terwujud derajat kesehatan masyarakat yang setinggi-tingginya, sebagai investasi bagi pembangunan sumber daya manusia yang produktif secara sosial dan ekonomis.(PP No 66 Tahun 2014)

Kesehatan Lingkungan sebagai salah satu upaya kesehatan ditujukan untuk mewujudkan kualitas

1) Email : adityapuspita331@gmail.com

2) Email : choirul1960@gmail.com lingkungan yang sehat, baik fisik, kimia, biologi, maupun sosial yang memungkinkan setiap orang mencapai derajat kesehatan yang setinggi-tingginya sebagaimana tercantum dalam Pasal 162 UndangUndang Nomor 36 Tahun 2009 tentang Kesehatan. Kesehatan Lingkungan diselenggarakan melalui Penyehatan, Pengamanan, dan Pengendalian, yang dilakukan terhadap lingkungan Permukiman, Tempat Kerja, tempat rekreasi, serta tempat dan fasilitas umum. (UU No 36 Tahun 2009)

Keslingmas Vol. 35 Hal. 278-396 Desember 2016 | 351 
Untuk mencapai tujuan di atas maka diperlukan suatu upaya kesehatan yang terpadu, menyeluruh, terarah, dan berkesinambungan dalam berbagai bidang untuk mencapai derajat kesehatan yang optimal bagi masyarakat. Upaya-upaya kesehatan itu yaitu dengan pendekatan, pemeliharaan, dan peningkatan kesehatan (promote), pencegahan penyakit (preventij), dan pengobatan penyakit(kuratij).

Kesehatan lingkungan ditekankan pada upaya pencegahan penyakit (preventij) salah satunya adalah pencegahan penyakit berbasis lingkungan menyerang masyarakat diakibatkan karena kebersihan lingkungan yang buruk dan kebiasaan buruk yang mencemari lingkungan tersebut, hal ini dapat menyebabkan penyakit dibawa oleh kotoran yang ada di lingkungan bebas baik secara langsung maupun tidak langsung salah satunya adalah penyakit diare. Penyakit diare merupakan masalah kesehatan masyarakat dan dikenal sejak zaman Hippocrates. Sampai saat ini di negara berkembang seperti Indonesia masih menjadi masalah utama. (M.C Widjaja, 2002). Diare merupakan suatu penyakit dengan tanda-tanda adanya perubahan bentuk dan konsistensi dari tinja, yang melembek sampai mencair dan bertambahnya frekuensi buang air besar biasanya tiga kali atau lebih dalam sehari.(Depkes RI, 2005).

Faktor risiko yang mempengarui kejadian diare antar lain penggunaan sarana air bersih, jamban keluarga, pembuangan sampah, pembuangan air limbah, dan pengolahan makanan dan minuman.

Di dalam sarana sanitasi, air bertindak sebagai tempat berkembangbiak mikroorganisme dan dapat berperan sebagai media penularan ke tubuh manusia. Dalam hubungannya dengan diare, sarana sanitasi berupa penyediaan air bersih dan jamban sangat memegang peranan penting untuk menekan kejadian diare.(Depkes RI, 2007)

Keberadaan sampah juga erat kaitannya dengan kesehatan masyarakat, karena pada sampah dapat hidup berbagai mikroorganisme penyebab penyakit (bacteriapathogen) dan juga binatang sebagai pemindah ataupun penyebar penyakit (vektor) (Notoatmojo,2007). Penanganan sampah yang tidak memadai, penanganan dan pengelolaan septic tank yang tidak memenuhi persyaratan menjadi penyebab utama timbulnya pencemaran mikroorganisme berbahaya pada air terutama Escherichia coli dan Coliform, apabila dikonsumsi oleh manusia akan mengakibatkan penyakit pada saluran pencernaan seperti diare.

Penyakit diare di Indonesia masih sulit diatasi, hal ini ditunjukkan masih tingginya morbisitas dan mortalitas. Hasil survei Subdit Diare, Departemen Kesehatan (sekarang Kementerian Kesehatan) dari tahun 2000 s/d 2010 terlihat kecenderungan insidens meningkat. Pada tahun 2000 IR Diare 301/1000 penduduk, tahun 2003 naik menjadi 374/1000 penduduk, tahun 2006 naik menjadi 423/1000 penduduk, dan tahun 2010 menjadi 411/1000 penduduk. Selain itu KlB juga masih terjadi , dengan Case Fertility Rate (CFR) yang masih tinggi. Pada tahun 2008 terjadi KLB 69 Kecamatan dengan jumlah kasus 8133 orang, kematian 239 orang (CFR 2,74\%). Pada tahun 2009 terjadi KLB di 24 kecamatan dengan jumlah kasus 5.756 orang, dengan kematian 100 orang CFR (CFR 1,74\%), sedangkan tahun 2010 terjadi KLB diare di 33 kecamatan dengan jumlah penderita 4204 dengan kematian 73 orang (CFR 1,74\%). (Buletin diare Kemenkes R1. 2011)

Berdasarkan data program P2M DKK Banyumas tahun 2014 kasus diare tertinggi di Wilayah Kerja Puskesmas Karanglewas sebanyak 1273 kasus dengan IR 20,26/1000 penduduk. Menurut data Puskesmas Karanglewas Kabupaten Banyumas lima tahun terakhir jumlah penderita diare fluktuatif. Tahun 2009 IR diare 8,06/1000 penduduk, tahun 2010 IR diare 13,97/1000 penduduk, tahun 2011 IR diare 9,69/1000 penduduk, tahun 2012 IR diare 13,38/1000 penduduk, tahun 2013 IR kasus diare $14,59 / 1000$ penduduk dan peningkatan yang cukup tajam terjadi di tahun 2014 dengan IR 20,26/1000 penduduk.(Profil Dinkes BMS, 2014)

Di wilayah kerja Puskesmas Karanglewas, desa tinggi kasus diare yaitu Desa Pangebatan yang sumber airnya masih menggunakan sumur gali dengan menggunakan katrol, ataupun dengan pompa listrik. Hasil pengamatan peneliti peletakan ember katrol masih sembarangan yang memungkinkan ember tersebut tercemar oleh bakteri. Kondisi fisik sumur gali yang tidak memenuhi syarat, jarak sumur gali dengan septictank yang $<11 \mathrm{~m}$ beresiko tercemar penyakit diare infeksi jika digunakan untuk kebutuhan sehari-hari.

Hasil penelitian Andik Pegiarto tahun 2004 di Wilayah Kerja Puskesmas Purwokerto Timur I terdapat hubungan yang bermakna antara kualitas bekteriologis yang tidak memenuhi syarat dengan kejadian diare. Hasil selanjutnya terdapat hubungan bermakna antara perilaku dengan kejadian diare yang berarti perilaku yang tidak baik mempunyai risiko terkena diare lebih besar dari orang yang berperilaku baik. (Andik Pegiarto, 2004).

Tujuan Penelitian ini adalahmengetahui hubungan sanitasi sumur gali dan kualitas bakteriologis dengan prevalensi diare infeksi di Desa Pangebatan Kecamatan Karanglewas, Kabupaten Banyumas.

\section{BAHAN DAN METODE}

Penelitian ini menggunakan metode analitik dengan pendekatan Cross Sectional dimana peneliti ingin mempelajari hubungan sanitasi sumur gali dan kualitas bakteriologis dengan prevalesi diare infeksi. Populasi penelitian ini adalah seluruh sumur di Desa Pangebatan, yaitu 168 SGL. Peneliti menggunakan teknik random sampling dengan metode cluster sampling, mengambil 20\% dari jumlah sumur 168 
buah yaitu 34 sampel. Metode pengumpulan data yang dilakukan adalah wawancara dengan menggunakan kuesioner penelitian, observasi dengan cara pengamatan terhadap obyek penelitian dan pengukuran terhadap parameter yang diteliti dalam hal ini adalah kandungan bakteriologis pada air sumur gali yang digunakan untuk penelitian.

\section{III.HASIL DAN PEMBAHASAN}

\section{Hasil}

Desa Pangebatan merupakan salah satu desa di Kecamatan Karanglewas, Kabupaten Banyumas yang letaknya paling timur dengan luas wilayah 185,9200 ha, secara geografis berbatasan dengan Desa Karanglewas Kidul di sebelah utara, dengan Desa Tamansari di sebelah barat, dengan Desa Kediri di sebelah selatan, dengan Desa Kedung Wringin dan Kelurahan Pasirmuncang di sebelah timur.

Tingkat pendidikan penduduk masih rendah ratarata lulusan SD dan SMP, mata pencaharian penduduk sebagian besar adalah buruh harian lepas yang bekerja di kota.

Secara topografis, Desa Pangebatan berada pada ketinggian $75 \mathrm{~m}$ dari permukaan laut (termasuk daerah dataran rendah). Sehingga banyak warga yang masih menggunakan sarana sumur gali untuk memenuhi kebutuhan sehari-harinya.

Data penderita diare tahun 2014 yang didapat dari Puskesmas Karanglewas tidak dipisah antara diare infeksi dan non infeksi sehingga menyulitkan tindakan selanjutnya termasuk mencari penyebab diare yang diderita pasien.

Dengan mengambil satu Desa tertinggi penderita diare yaitu Desa Pangebatan, dengan jumlah responden 34 ditemukan kasus diare sebesar 13 kasus, yang mengalami gejala diantaranya demam, nyeri kepala, badan lesu, mual, BAB lembek, tinja bau amis, dan warna tinja putih. Gejala tersebut adalah gejala yang mengacu pada diare infeksi. Namun, dari 13 responden tersebut satu gejala tidak ditemukan, yaitu muntah. Jadi dipastikan bahwa diare tersebut bukan termasuk diare infeksi.

Hasil analisis bivariat hubungan Sanitasi Sumur Gali dengan Prevalensi Diare

Tabel 4.29 : Hubungan sanitasi SGL dengan prevalensi diare di Desa Pangebatan, Kecamatan Karanglewas, Banyumas tahun 2016

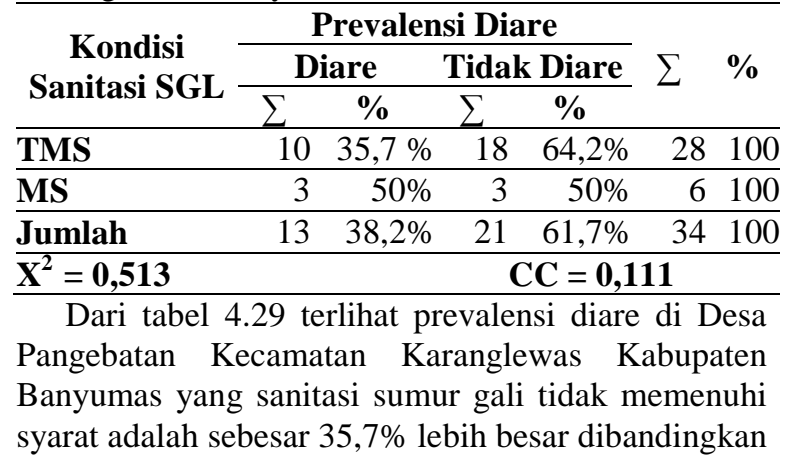

dengan prevalensi diare yang sanitasi sumur gali memenuhi syarat yaitu sebesar $50 \%$.

Hasil uji statistik dengan $\mathrm{X}^{2}$ diperoleh nilai $\mathrm{P}$ (taraf signifikansi) $=0,513$ (nilai $\mathrm{P}>0,05$ ) artinya tidak terdapat hubungan bermakna secara statistik antara sanitasi sumur gali dengan prevalensi diare di Desa Pangebatan Kecamatan Karanglewas, Kabupaten Banyumas. Dan diperkuat dengan Contingency Coefficient sebesar 0,111 yang dimana hubungan sanitasi sumur gali dengan prevalensi diare terdapat ketekaitan yang lemah antara variabel.

a. Hubungan Kualitas Bakteriologis dengan Prevalensi Diare

Tabel 4.30 : Hubungan kualitas bakteriologis dengan prevalensi diare di Desa Pangebatan Kecamatan Karanglewas Kabupaten Banyumas

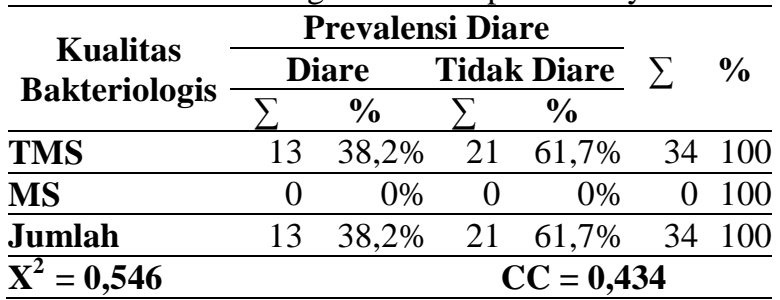

Dari tabel 4.30 sebanyak 34 sampel air sumur gali Desa Pangebatan Kecamatan Karanglewas yang diperiksa kualitas bakteriologisnya, semua sampel tidak memenuhi syarat karena kandungan Coliform lebih dari 50/100 ml menurut Permenkes RI Nomor : 416/Menkes/Per/IX/1990. Hubungan prevalensi diare dengan kualitas bakteriologis yang tidak memenuhi syarat adalah sebesar 38,2\% .

Dari hasil uji hubungan statistic $\mathrm{X}^{2}$ diperoleh nilai $\mathrm{P}$ (taraf signifikansi) $=0,546$ (nilai $\mathrm{P}>0,05$ ) artinya tidak terdapat hubungan bermakna secara statistik antara kualitas bakteriologis dengan prevalensi diare di Desa Pangebatan, Kecamatan Karanglewas, Kabupaten Banyumas. Dan diperkuat dengan Contingency Coefficient sebesar 0,434 yang dimana hubungan kualitas bakteriologis air sumur gali dengan prevalensi diare terdapat keterkaitan yang lemah antara variabel.

b. Hubungan Perilaku Pengguna Sumur Gali dengan Prevalensi Diare

Tabel 4.30 : Hubungan Perilaku Pengguna SGL dengan Prevalensi Diare Di Desa Pangebatan Kecamatan Karanglewas Kabupaten Banyumas Tahun 2016

\begin{tabular}{|c|c|c|c|c|c|c|}
\hline \multirow{3}{*}{$\begin{array}{l}\text { Perilaku } \\
\text { Pengguna } \\
\text { SGL }\end{array}$} & \multicolumn{4}{|c|}{ Prevalensi Diare } & \multirow{3}{*}{$\sum$} & \multirow{3}{*}{$\%$} \\
\hline & \multicolumn{2}{|c|}{ Diare } & \multicolumn{2}{|c|}{ Tidak Diare } & & \\
\hline & $\sum$ & $\%$ & $\sum$ & $\%$ & & \\
\hline TB & 11 & $52,3 \%$ & 10 & $47,6 \%$ & 21 & 100 \\
\hline B & 2 & $15,3 \%$ & 11 & $84,6 \%$ & 13 & 100 \\
\hline Jumlah & 13 & $38,2 \%$ & 21 & $61,7 \%$ & 34 & 100 \\
\hline$\overline{X^{2}=0,031}$ & \multicolumn{6}{|c|}{$C C=0,347$} \\
\hline
\end{tabular}

Dari tabel 4.31 terlihat prevalensi diare di Desa Pangebatan Kecamatan Karanglewas yang perilaku pengguna sumur gali tidak baik/buruk adalah sebesar 52,3\% lebih besar dibandingkan 
dengan prevalensi diare yang perilaku pengguna sumur galinya baik yaitu 15,3\%.

Dari hasil uji hubungan statistik $\mathrm{X}^{2}$ diperoleh nilai $\mathrm{P}$ (taraf signifikansi) $=0,031$ (nilai $\mathrm{P}<0,05)$ artinya terdapat hubungan bermakna secara statistik antara perilaku pengguna sumur gali dengan prevalensi diare di Desa Pangebatan, Kecamatan Karanglewas, Kabupaten Banyumas. Namun, hasil Contingency Coefficient menunjukkan angka sebesar 0,347 dimana hubungan perilaku pengguna sumur gali dengan prevalensi diare keterkaitannya lemah antara variabel.

\section{Pembahasan}

Sanitasi sumur gali terdiri dari sepuluh dengan menggunakan checklist dari 34 responden. Sumur yang tidak memenuhi syarat sanitasi sumur gali (tabel 4.8) dikarenakan kondisi fisik dari sumur gali yang berada di Desa Pangebatan Kecamatan Karanglewas Kabupaten Banyumas.

Variabel sanitasi sumur gali diantaranya jarak sumur gali dengan jamban, konstruksi dinding sumur, lantai sumur, bibir sumur, tali dan ember timba dan lain sebagainya. Desa Pangebatan, Kecamatan Karanglewas, Kabupaten Banyumas sumur gali yang jaraknya <11 meter dari jamban ada 31 (91\%). Adanya jarak antara sumur gali dengan jamban adalah >11 meter bertujuan untuk mencegah bakteri yang terbawa oleh air masuk ke dalam air sumur gali. (Soeparman dan Suparmin, 2001, hal. 49)

Dinding kedap air pada sumur gali harus dibuat agar perembesan air permukaan yang telah tercemar tidak terjadi. Kedalaman 3 meter bertujuan agar bakteri pada umumnya tidak dapat hidup lagi pada kedalaman tersebut. Kira-kira 1,5 meter berikutnya ke bawah, dinding ini tidak dibuat tembok yang tidak disemen, tujuannya untuk mencegah runtuhnya tanah.

Tidak terdapat keretakan pada dinding sumur gali dan lantai sumur dimaksudkan agar bakteri tidak dapat masuk ke dalam sumur melalui celah-celah retakan yang terdapat pada dinding sumur gali.

SPAL pada sumur gali di Desa Pangebatan 83\% rusak dan juga termasuk yang tidak memiliki SPAL. Jarak SPAL dari sumur gali yang disyaratkan adalah $>11 \mathrm{~m}$, sama halnya dengan jarak sumur gali ke sumber pencemar untuk mencegah bakteri terbawa air masuk ke dalam sumur gali. (Soeparman dan Suparmin, 2001, hal. 49 )

Posisi tali timba dan ember yang digunakan oleh 34 responden di Desa Pangebatan, 19 diantaranya tidak menggantung. Padahal dengan posisi menggantung dimaksudkan agar tidak terjadi kontak langsung timba oleh lantai tanah yang dapat mengkontaminasi timba dan tali oleh kotoran.

Dari semua responden, satupun tidak ada yang melakukan desinfeksi pada sumur galinya. Secara umum desinfeksi sumur gali dapat menggunakan kaporit yang berguna membunuh bakteri dan virus dalam air. (www.saringan air.com)
Air merupakan benda yang sangat penting untuk berlangsungnya kehidupan makhluk di dunia ini. Tanpa air dari segi kualitas dan kuantitas akan menyulitkan semua segi kehidupan. Namun, disamping itu air juga mempunyai peranan yang sangat penting dalam penularan penyakit.

Dalam penyediaan air bersih terdapat beberapa cara, salah satunya dengan sumur gali. Dalam pembuatan sumur gali perlu diperhatikan beberapa faktor yang berhubungan dengan sanitasi, yaitu dinding, lantai, bibir sumur, dll.

Dalam uji signifikasi yang dipakai adalah 0,05 menggunakan tabel kontingensi 2x2 dengan degree of freedom $(\mathrm{df})=1$ dan didapat nilai $\mathrm{P}$ (Taraf Signifikansi) $=0,513$ yang berarti tidak ada hubungan antara sanitasi sumur gali terhadap prevalensi diare di Desa Pangebatan Kecamatan Karanglewas, Kabupaten Banyumas.

Dari hasil uji hubungan tersebut dapat diketahui bahwa prevalensi diare lebih banyak terjadi pada responden yang sanitasi sumur galinya tidak memenuhi syarat. Dan jika melihat tabel 4.29, responden yang sanitasi sumur galinya buruk namun tidak terjangkit diare sebanyak $64 \%$ dari 34 responden. Jadi kemungkinan penyebab diare bukanlah akibat sanitasi sumur gali yang buruk saja. Penyebab lain diantaranya ada gangguan penyerapan makanan atau malabsorbsi, alergi atau tidak cocok dengan makanan, keracunan bahan kimia atau racun yang terkandung dalam makanan, imunodefisiensi atau kekebalan tubuh menurun, dan penyebab lain yang berhubungan dengan psikologi dan pikiran seseorang. (http://www.infodiknas.com/diare-akutkarena-infeksi.html)

Tidak ada hubungan sanitasi sumur gali dengan diare infeksi disebabkan oleh beberapa faktor lain, menurut Anderson dan Arnstein (dalam Soeparman dan Suparmin, 2001, Hal. 7) terjadinya proses penularan penyakit diperlukan faktor sebagai berikut:

a. Kuman penyebab penyakit,

b. Sumber infeksi (reservoir) dari kuman penyebab,

c. Cara keluar dari sumber

d. Cara berpindah dari sumber ke inang (host) baru yang potensial

e. Cara masuk ke inang yang baru

f. Inang yang peka (susceptible).

Ada baiknya untuk mencegah terjadinya penyakit diare infeksiyang penularannya melalui air (water born disease), maka perlu diperhatikan sarana sumur gali untuk kebutuhan sehari-hari. Perawatan sumur gali penting dilakukan dengan pembersihan dinding secara berkala, perbaikan konstruksi yang retak dan rusak, permbersihan saluran pembuanga agar tidak timbul genangan, dan pemberian kaporit sebagai desinfeksi.

Masyarakat sebagai pelaku kesehatan lingkungan berperan penting dalam pemeliharaan sarana kesehatan. Dikatakan di atas bahwa air sangat berperan penting dalam kehidupan sehari-hari yang dikendalikan oleh masyarakat tersebut. Dapat 
disimpulkan bahwa perilaku pengguna sumur gali yang baik, saniter dan tertib akan menghasilkan air sumur gali yang bersih, minimal secara fisik.

Dalam uji level signifikansi yang dipakai adalah 0,05 menggunakan tabel kontingensi 2x2 dengan degree of freedom $(\mathrm{df})=1$ dan didapatkan nilai $\mathrm{P}$ (taraf signifikasi) $=0,031$ yang berarti bahwa terdapat hubungan antara perilaku pengguna sumur gali dengan prevalensi diare di Desa Pangebatan Kecamatan Karanglewas, Kabupaten Banyumas.

Dari 34 sampel, yang perilakunya tidak baik dan terserang diare sebesar 11 (52,2\%) namun berbeda sedikit dengan responden yang tidak diare namun perilakunya tidak baik yaitu 10 (47\%).

Dari hasil pengamatan di lapangan menunjukkan perilaku masyarakat tidak baik dalam pemanfaatan air sumur, misalnya tidak mencuci tangan saat akan menimba, tidak mencuci ember timba saat akan digunakan, lantai sumur tidak dibersihkan sehingga timbul lumut dan licin, dan dari 34 responden tidak ada satupun yang menggunakan chlor sebagai desinfeksi agar membunuh bakteri Shigella, Salmonella, dan Retroviridae sebagai salah satu bakteri penyebab diare infeksi dan muntaber.

Upaya yang harus dilakukan masyarakat untuk mencegah terjadinya diare yaitu dengan merubah perilaku pengguna diantaranya membersihkan secara berkala sumur gali, misal membersihkan lumut dan tumbuhan pengganggu di dinding sumur, mencuci tangan sebelum mengambil air, membersihkan ember sebelum digunakan, membersihkan lantai secara rutin dan melakukan desinfeksi secara berkala.

\section{IV.KESIMPULAN}

Dari 34 responden yang ditemukan diare 13 responden, namun tidak ada yang menderita diare infeksi. Gejala yang ditimbulkan dari diare tersebut yaitu deman, nyeri kepala, badan lesu, mual, BAB lembek, tinja bau amis, dan warna tinja putih. Tidak mengindikasi diare infeksi dikarenakan tidak terdapat gejala muntah. Kondisi sanitasi sumur gali yang telah diinspeksi sebanyak 34 sumur. Sumur gali yang tidak memenuhi syarat 28 (82\%) dan 6 (18\%) yang memenuhi syarat.

Hasil pemeriksaan kualitas bakteriologis air bersih Desa Pangebatan dari 34 sampel yang diperiksa semua sampel menunjukan angka $>50 / 100$ ml sehingga semua tidak memenuhi syarat kualitas bakteriologis.

Hasil analisis data menunjukan tidak ada hubungan sanitasi sumur gali dengan prevalensi diare di Desa Pangebatan, Kabupaten Banyumas dimana hasil uji statistik dengan $\mathrm{X}^{2}$ diperoleh nilai $\mathrm{P}$ (taraf signifikansi) $=0,513$ (nilai $\mathrm{P}>0,05$ ). Dan diperkuat dengan Contingency Coefficient sebesar 0,111 yang dimana hubungan sanitasi sumur gali dengan prevalensi diare terdapat ketekaitan yang lemah antara variabel.

Hasil analisis data menunjukkan tidak ada hubungan kualitas bakteriologis dengan prevalensi diare di Desa Pangebatan, Kabupaten Banyumas. Dari hasil uji hubungan statistic $\mathrm{X}^{2}$ diperoleh nilai $\mathrm{P}$ (taraf signifikansi) $=0,546$ (nilai $\mathrm{P}>0,05$ ) artinya tidak terdapat hubungan bermakna secara statistik antara kualitas bakteriologis dengan prevalensi diare. Dan diperkuat dengan Contingency Coefficient sebesar 0,434 yang dimana hubungan kualitas bakteriologis air sumur gali dengan prevalensi diare terdapat keterkaitan yang lemah antara variabel.

Dari hasil analisis data menunjukan perilaku 34 responden, 12 (35\%) baik dalam perilaku penggunaan sumur gali dan 24 (65\%) tidak baik dalam penggunaan sumur gali. Ada hubungan perilaku pengguna sumur gali dengan prevalensi diare di Desa Pangebatan, Kabupaten Banyumas. Dari hasil uji hubungan statistik $\mathrm{X}^{2}$ diperoleh nilai $\mathrm{P}$ (taraf signifikansi) $=0,031$ (nilai $\mathrm{P}<0,05)$ artinya terdapat hubungan bermakna secara statistik antara perilaku pengguna sumur gali dengan prevalensi diare. Namun, hasil Contingency Coefficient menunjukkan angka sebesar 0,347 dimana hubungan perilaku pengguna sumur gali dengan prevalensi diare keterkaitannya lemah antara variabel.

\section{DAFTAR PUSTAKA}

ArisSantjaka, 2011, Statistik Untuk Penelitian Kesehatan, Yogyakarta : Nuha Medika.

AzrulAzwar, 1986 Pengantar Ilmu Kesehatan Lingkungan, Jakarta: Mutiara Sumber Widya.

Devi Artanti, 2007, Hubungan Tingkat Risiko Pencemaran DenganKandungan Bakteri Coliform Air Sumur Gali Di RT $05 \quad$ RW III Desa Pejagoan Kecamatan Pejagoan Kabupaten BanyumasTahun 2007, KaryaTulis Ilmiah, Purwokerto: Poltekkes Kemenkes Semarang.

Dian Esti, 2011, Studi Keadaan Sarana Sanitasi Rumah Penderita Diare di Desa Pedurungan Kecamatan Taman Kabupaten Pemalang Tahun 2011, Karya Tulis Ilmiah, Purwokerto: Poltekkes Kemenkes Semarang.

Depkes RI, 2000, Pedoman Pelaksanaan Program P2 Diare, Jakarta : Depkes RI

,2005, Pedoman Pelaksanaan

P2 Diare, Jakarta : Depkes RI.

Program

, 2007, Pedoman Pelaksanaan Program P2

Diare, Jakarta : Depkes RI

, 2007, Pelatihan Penyediaan Air, Jakarta :Depkes RI 
Dinas Kesehatan Kabupaten Banyumas, 2014, Data Angka Kesakitan Diare Di Kabupaten Banyumas, Banyumas: Dinas Kesehatan.

Direktorat Jendral Pencegahan dan Pemberantasan PenyakitMenular (P3M) Depkes RI, 1985, Buku Pedoman untuk Kader Pembangunan Desa Dalam Pemberantasan Penyakit Diare. Jakarta: Depkes.

Hefni Effendi, 2003, Telaah Kualitas Air, Yogyakarta: Kanisius.

http://fkm.undip.ac.id/sistem-informasi/dataskripsi/2534.pdf, diakses pada tanggal 17 September 2015. Pukul $15.45 \quad$ WIB.

http://www.infodiknas.com/diare-akut- karenainfeksi.html diakses pada tanggal 9 Februari 2016. Pukul 10.13 WIB

http://pdfqueen.com/pdf/in/rahmawatiunhasbab3> , diakses pada tanggal 22 Desember 2015. Pukul 19.23 WIB.

Indan Entjang, 2000, Ilmu Kesehatan Masyarakat, Jakarta: Citra Aditya Bakti.
Kemenkes RI, 2011, Buletin Diare, TentangSituasi Diare Di Indonesia, Jakarta: Kemenkes RI.

MC Widjaja, 2002, Mengatasi Diare dan Keracunan pada Balita, Jakarta: Kawan Pustaka.

Peraturan Pemerintah Republik Indonesia, No 66 Tahun 2014, Tentang Kesehatan Lingkungan, Jakarta: PP RI.

Permenkes RI, No:416/MEN.KES.PER/IX/1990, tentang Syarat-syarat dan Pengawasan Kualitas Air, Jakarta: Permenkes RI.

Profil Puskesmas Karanglewas Kecamatan Karanglewas Kabupaten Banyumas.2014.

Soekidjo Notoatmodjo, 2007, Kesehatan Mayarakat Ilmu dan Seni, Jakarta : Rineka Citra.

Soeparman, 2006, Sarana Air Bersih dan Inspeksinya, Purwokerto.

Undang-undang Republik Indonesia, No.36 Tahun 2009, Tentang Kesehatan. Jakarta: Republik Indonesia. 